\title{
Integrating Ranch Forage Production, Cattle Performance, and Economics in Ranch Management Systems for Southern Florida
}

\author{
J. D. Arthington, ${ }^{1}$ F. M. Roka, ${ }^{2}$ J. J. Mullahey, ${ }^{3}$ S. W. Coleman, ${ }^{4}$ \\ R. M. Muchovej, ${ }^{5}$ L. O. Lollis, ${ }^{6}$ and D. Hitchcock ${ }^{7}$ \\ Authors are ${ }^{1}$ Associate Professor, University of Florida-IFAS, Range Cattle Research and Education Center, Ona, FL 33865; \\ ${ }^{2}$ Associate Professor, University of Florida-IFAS, Southwest Florida Research and Education Center, Immokalee, FL 34142; \\ ${ }^{3}$ Professor, University of Florida-IFAS, West Florida Research and Education Center, Milton, FL 32583; \\ ${ }^{4}$ Research Animal Scientist, USDA, ARS, Subtropical Agricultural Research Station, Brooksville, FL 34601; \\ ${ }^{5}$ Assistant Extension Specialist, University of Florida-IFAS, Southwest Florida Research and Education Center, \\ Immokalee, FL 34142; ' Ranch Manager, MacArthur Agro-ecology Research Center, Lake Placid, FL 33852; and \\ ${ }^{7}$ Graduate Research Assistant, Department of Statistics, University of Florida, Gainesville, FL 32611.
}

\begin{abstract}
The presence of grazing cattle near open waterways has created environmental concerns related to the potential for water contamination. In Florida the removal of cattle from grazing landscapes or decreasing stocking density is being investigated as one option to improve the quality of surface water runoff draining into Lake Okeechobee, Florida. The objective of this study was to determine the effects of stocking rate on cow-calf performance, forage availability and quality, and ranch economic performance. Experimental pastures were established on a southern Florida cow-calf operation with stocking rates of $0.58,1.01$, and 1.35 $\mathrm{ha} \cdot \mathrm{cow}^{-1}$ on summer pastures and $0.93,1.62$, and $2.16 \mathrm{ha} \cdot \mathrm{cow}^{-1}$ on winter pastures, corresponding to high, medium, and low rates, respectively. The study was conducted over 4 consecutive production years. Cow body condition scores (BCS), pregnancy rate, and calf average daily gain were used as measures of animal performance. Forage utilization was estimated by measuring the difference between forage yield inside and outside grazing exclusion cages and forage quality by crude protein and in vitro organic matter digestibility. Forage yield, utilization, and quality were not significantly affected by stocking rate. Although statistically not significant $(P=0.17)$, cattle in the high stocking rate experienced a numerically greater loss of BCS following the winter grazing period, but stocking rate did not affect pregnancy rate or calf gains. Production ( $k g$ weaned calves $\bullet \mathrm{ha}^{-1}$ ) was increased $(P<0.01)$ for a high stocking rate compared with medium and low stocking rates. Overall ranch profitability will decrease as stocking rates decline. Ranch revenues decrease one-for-one as stocking rates decrease. At the same time, unit cow costs increase at an increasing rate as fewer brood cows are left to support the ranch's fixed cost structure.
\end{abstract}

\section{Resumen}

La presencia de ganado apacentando cerca de las vías acuáticas ha creado una preocupación ambiental relacionada con el potencial de contaminación del agua. En Florida, la remoción del ganado de los pastizales o la disminución de la densidad de carga animal están siendo investigadas como una opción para mejorar la calidad del agua del escurrimiento superficial que drena en el lago Okeechobee en Florida. El objetivo de este estudio fue determinar los efectos de la carga animal en el comportamiento productivo del binomio vaca-becerro, la disponibilidad y calidad del forraje y los aspectos económicos del rancho. Las praderas experimentales se establecieron en el sur de Florida en un rancho dedicado al sistema vaca-becerro con cargas animal de 0.58 , 1.01, y $1.35 \mathrm{ha} \cdot \mathrm{vaca}^{-1}$ para las praderas de verano y de $0.93,1.62$, y $2.16 \mathrm{ha} \cdot \mathrm{vaca}^{-1}$ para las praderas de invierno, que corresponden a cargas alta, media y baja respectivamente. El estudio se condujo durante cuatro años productivos consecutivos. La clasificación de la condición corporal (BCS), tasa de preñez y las ganancias de peso diarias promedio de los becerros se usaron como medidas del comportamiento animal. La utilización del forraje fue estimada midiendo la diferencia entre el rendimiento de forraje dentro y fuera de jaulas de exclusión y la calidad del forraje determinando la proteína cruda y la digestibilidad in vitro de la materia orgánica. El rendimiento de forraje, la utilización y calidad no fueron afectadas significativamente por la carga animal. Aunque estadísticamente las diferencias no fueron significativas $(P=0.17)$, el ganado en la carga alta experimentó una pérdida numéricamente mayor de la condición corporal después periodo de apacentamiento en invierno, pero la carga animal no afectó la tasa de preñez o la ganancia de peso de los becerros. La producción $\left(\mathrm{kg}\right.$ de becerro destetado $\cdot \mathrm{ha}^{-1}$ ) se incrementó $(P<0.01)$ en la carga animal alta en comparación con las cargas media y baja. La rentabilidad global del rancho decrecerá conforme la carga animal disminuye. Los ingresos del rancho disminuyen al uno por uno conforme la carga animal disminuye. Al mismo tiempo, los costos unitarios por vaca se incrementan al aumentar la carga y conforme una pocas vacas con cría son dejadas para soportar la estructura fija de costos del rancho.

Key Words: forage, grazing, beef cattle, stocking density

This paper is contribution 97 of the MacArthur Agro-ecology Research Center and was approved for publication as Journal Series no. R-10196 of the Florida Agriculture Experiment Station. Research was supported in part by USDA/NRICGP Agricultural Systems Program Grant 97-35108-5125 and the Florida Agricultural Experiment Station.

Correspondence: J. D. Arthington, University of Florida-IFAS, Range Cattle Research and Education Center, Ona, FL 33865. Email: jarth@ufl.edu

Manuscript received 3 April 2005; manuscript accepted 22 October 2006. 


\section{INTRODUCTION}

Maintenance of an optimal stocking rate is a balance between providing an adequate forage base to support animal performance (reproduction and growth) while optimizing the amount of beef production per ha used. Once a maximal threshold is achieved, the amount of beef produced per hectare decreases with an increasing stocking rate. This economic consideration may change, however, when environmental concerns interact with efforts to maximize ranch production efficiency. In Florida the presence of grazing cattle near open waterways has created environmental concerns related to the potential for water contamination. The removal of cattle from grazing landscapes or decreasing stocking density is being investigated as one option to improve the quality of surface water runoff draining into Lake Okeechobee, Florida.

Florida ranks third among states east of the Mississippi River and 15th nationally in total number of beef cows in 2005 (USDA-NASS 2006). Much of southern Florida was once native, subtropical, wet-prairie ecosystems. While much of this region has been drained and converted to improved pasture, some wetland prairies remain. Utilization of wetland prairies for cattle grazing is critical to beef cattle production in Florida. For many ranches, wetland prairies are grazed during the winter months when forage productivity is low on upland improved pastures. The objective of this study was to determine the effects of cattle stocking rate on cow and calf performance in a grazing system utilizing unimproved bahiagrass (Paspalum notatum Flügge) pastures during the winter and improved bahiagrass pastures during the summer. This paper is part of a series that address the influence of different stocking densities on ranch management systems, including impacts on phosphorus budgets (Swain et al. 2007), water quality and soils (Capece et al. 2007), and bioindicators (McSorley and Tanner 2007).

\section{MATERIALS AND METHODS}

\section{Study Site}

This study was conducted over 4 complete beef cow production cycles (years) from 1999 to 2003 at the MacArthur Agroecology Research Center, located near Lake Placid, Florida (lat $27^{\circ} 09^{\prime} \mathrm{N}$; long $\left.81^{\circ} 12^{\prime} \mathrm{W}\right)$. MacArthur Agro-ecology Research Center is home to a commercial cow-calf operation known as Buck Island Ranch. Approximately 3000 brood cows are managed on 4290 ha.

Experimental units consisted of 8 summer and winter paddocks. Summer paddocks averaged 20.3 ha (range $=19.0-22.1$ ha) and consisted of established bahiagrass on well-drained soils. Winter paddocks averaged 32.2 ha $($ range $=30.3-34.1$ ) and consisted of mixed forages, predominantly bahiagrass, established on poorly drained soils. More details on pasture soils and vegetation are provided in Swain et al. (2007).

\section{Animals, Pastures, and Stocking Rates}

Four stocking rate treatments were used on pastures during both the summer and winter grazing seasons. Stocking rate treat- ments included $0,15,20$, and $35 \mathrm{cow}$-calf pairs per paddock to represent nongrazed (control), low, medium, and high stocking rate treatments, respectively. These stocking rates represented $1.35,1.01$, and $0.58 \mathrm{ha} \cdot \mathrm{cow}^{-1}$ on summer pastures, and 2.16, 1.62 , and $0.93 \mathrm{ha} \cdot \mathrm{cow}^{-1}$ on the winter pastures, although actual densities varied somewhat because of variation in actual pasture size (Swain et al. 2007). The high-density stocking rate represents the current stocking rate of the commercial cow-calf operation at Buck Island Ranch and closely matches stocking rates on ranching operations in the surrounding area. The difference in animal densities in the summer and winter pastures was necessitated by differences in forage biomass production during the grazing period in these pastures. Summer, but not winter, pastures received a spring application of ammonium nitrate fertilizer $\left(56 \mathrm{~kg} \mathrm{~N} \cdot \mathrm{ha}^{-1}\right)$.

A spring drought in 1999 forced cattle to be transferred in May from the summer pastures to winter pastures. They were returned to summer pastures in June (approximately $3 \mathrm{wk}$ ) when adequate forage was available; therefore, cow data from Year 1 were not included in the 4-yr data set. Calf data for all 4 complete summer periods were collected and analyzed. Each annual production cycle started by putting pregnant, Brahmancrossbred cows (age range $=4-9 \mathrm{yr}$ ) onto winter pastures in November. All cows were exposed to bulls on winter pastures for 120 days starting in January. Cattle grazed continuously in the pastures and were provided with supplementary feed in the form of urea-fortified molasses $(16 \%$ crude protein; as fed basis; United States Sugar Corporation, Clewiston, FL) in the winter months and a free-choice trace mineral fortified salt mixture year-round (PDQ7; Lakeland Animal Nutrition, Lakeland, FL). Molasses and salt supplements were supplied in open tanks and mineral boxes and were moved regularly around the pasture. The average annual intake for each cow and calf pair was 310 and $11.5 \mathrm{~kg}$ for molasses and salt, respectively. Cow body condition was scored on a 1-9 scale ( $1=$ emaciated and $9=$ obese $)$ when they were moved to winter pastures (start of production cycle), moved to summer pastures, and at weaning (end of production cycle). Calf weight was collected when cows were moved into summer pastures and again at weaning.

\section{Forage Sampling and Analysis}

For the collection of forage samples, summer pastures were divided into 10 equal blocks, and winter pastures into 16 blocks. Nine $1.5-\mathrm{m}^{2}$ grazing exclusion cages were selectively placed in each pasture within a designated block. On the summer pastures, 9 of the 10 blocks had cages, and in the winter pasture 9 of the 16 blocks had cages. In addition to collecting forage from within the exclusion cages, a paired plot sample outside the cage was collected at the same time. The location for the paired plot was determined after each cage was relocated within the block. Following each sampling period the grazing exclusion cages were moved to a new area within the pasture block. The paired plot location contained forage that was similar in height and composition to the forage within the exclusion cage. Therefore, the forage yield in the cage represents nongrazed forage accumulation, and the forage in the paired plot represents the standing forage after grazing. Forage collections occurred at 3 times during the summer and winter grazing periods. On the 
summer pastures, forage was sampled in April (Start), July (Middle), and August (End) over all 4 years, with the exception of Middle and End collections in Year 3 and Start collection in Year 4. Forage sampling in the winter pastures was conducted in November (Start), February (Middle), and April (End) over all years, except Year 3 when much of the accumulated forage was destroyed by an inadvertent wild fire. Percentage forage utilization was calculated by subtracting the forage yield in the paired plot from the forage yield in the cage, dividing by the yield in the caged plot and multiplying by 100 . All forage samples were clipped at ground level and weighed. From each field sample, a subsample was dried in a forced-air oven to determine dry matter yield. Dried samples from the paired-plot harvest was ground and analyzed at the Forage Nutrition Laboratory at the University of Florida, Gainesville, for crude protein (CP) and in vitro organic matter digestibility (IVOMD). For determination of CP, samples were digested using a modification of the aluminum block digestion procedure of Gallaher et al. (1975). Sample weight was $0.25 \mathrm{~g}$, catalyst used was $1.5 \mathrm{~g}$ of $9: 1$ $\mathrm{K}_{2} \mathrm{SO}_{4}: \mathrm{CuSO}_{4}$, and digestion was conducted for at least $4 \mathrm{~h}$ at $375^{\circ} \mathrm{C}$ using $6 \mathrm{ml}$ of $\mathrm{H}_{2} \mathrm{SO}_{4}$ and $2 \mathrm{ml} \mathrm{H}_{2} \mathrm{O}_{2}$. Nitrogen concentration was determined by semiautomated colorimetry (Hambleton 1977). Analysis for IVOMD was performed by a modification of the 2-stage technique (Moore and Mott 1974).

Cow and calf performance and forage data were analyzed using the MIXED procedure of SAS (SAS Institute Inc., Cary, $\mathrm{NC)}$ in a completely randomized model with pasture as the experimental unit. The model statement contained the effects of treatment and time and the interaction of treatment $\times$ time. Data were analyzed using the animal(treatment) as the random variable. Treatment means were separated using least square means, and treatments were determined significantly different at $P<0.05$.

\section{Economic Analysis}

Five years of data were collected from the commercial operation at Buck Island Ranch (1999-2003). These data provided an annual itemized accounting of production costs, calving percentages, and calf weaning weights. The Standardized Performance Analysis (SPA) was developed with the support of the National Cattlemen Beef Association's Integrated Resource Management Committee to standardize procedures for reporting production and financial information from cow-calf operations. SPA allows for a consistent method of comparing ranch production data both across years and among other cow-calf operations. Further, by accounting for noncash costs such as livestock depreciation, SPA is able to provide a more accurate picture of long-term ranch profitability (McGrann 1995).

Annual input cost and price data were deflated by the Consumer Price Index (Bureau of Labor Statistics 2006). The first year of the study, 1999, was set as the base year. Inflationadjusted costs were grouped into 2 categories; those costs that were dependent on herd size and those costs that were independent of herd size. Herd-dependent costs included supplemental feed, veterinary supplies, pasture fertilization, day riders (labor), and pen and fence repairs. Herd-sizedependent costs remained fairly constant on a per head basis and were proportional to cow numbers.
Costs that are independent of herd size remain constant across years and do not change with the number of brood cows. Independent costs include equipment depreciation, office overhead, insurance, utilities, management salaries, accounting services, and property taxes. Buck Island Ranch does not pay property tax because of its nonprofit research status. In the current model, property taxes of $\$ 11 \mathrm{ha}^{-1}$ were added to overall costs to reflect what neighboring operations have to pay.

The terminology of "dependent" and "independent" costs used in this analysis is not to be confused with "variable" and "fixed" costs. The purpose of this analysis was to track how unit costs to raise a calf change as stocking rates change. The variable-fixed cost distinctions do not fully account for herd size differences. Costs such as supplies, travel, and accounting fees are considered "variable" but are, at the same time, independent of herd size.

The economic implications of changing stocking rates were analyzed by simulating the imposition of a particular stocking rate treatment over the entire Buck Island Ranch operation. The highest stocking rate treatment $\left(0.58 \mathrm{ha} \cdot \mathrm{cow}^{-1}\right.$ on summer pastures and $0.93 \mathrm{ha} \cdot \mathrm{cow}^{-1}$ on winter pastures) served as a starting point because it closely matches the stocking rate currently being maintained within the Buck Island Ranch commercial herd of 3000 brood cows. If the lower stocking rate treatments of 1.01 and $1.35 \mathrm{ha} \cdot \mathrm{cow}^{-1}$ on improved summer pastures and 1.62 and $2.16 \mathrm{ha} \cdot \mathrm{cow}^{-1}$ on unimproved winter pastures were to be imposed at Buck Island Ranch, the herd size would decrease to 1723 and 1289 brood cows, respectively. Since the highest stocking rate treatment represented the Ranch's current position, production data on calving percentages and weaning weights for the highest stocking rate treatment were taken to be the 5-yr average of Ranch performance statistics between 1999 and 2003. As lower stocking rates were imposed, production data were adjusted, if necessary, by the results of the animal performance data collected during the duration of the project. Costs that were dependent upon herd size were adjusted downward according to SPA data collected during the project period (1999-2003). Costs independent of herd size remained at the same level as at the initial stocking rate (3000 head). For each stocking rate, total operating cost, unit calf cost, and break-even calf prices were calculated.

\section{RESULTS AND DISCUSSION}

\section{Forage Quality and Availability}

Average available winter forage was greatest $(P<0.001)$ in Year 1 compared to Years 2 and 4 (data not collected during winter of Year 3 because of wild fire) (4 940, 3 100, and $3460 \mathrm{~kg} \cdot \mathrm{ha}^{-1}$ for Years 1, 2, and 4, respectively; pooled SEM $=219$ ). No differences in available winter forage among the stocking rate treatments were observed $(P=0.91$; Table 1$)$; however, available forage declined $(P<0.05)$ from the start to end of winter grazing for all stocking rate treatments, including the nongrazed control (Table 1).

Average available summer forage was greatest $(P<0.01)$ in Year 2 compared to Years 1, 3, and 4 (2 850, 3 470, 2 470, and $2620 \mathrm{~kg} \cdot \mathrm{ha}^{-1}$ for Years 1, 2, 3 and 4, respectively; pooled $\mathrm{SEM}=131)$. Average available forage did not differ 
Table 1. Effect of stocking rate treatment on average available forage at the start and end of winter grazing over 3 complete production years. ${ }^{1}$

\begin{tabular}{lcccc}
\hline $\begin{array}{c}\text { Collection } \\
\text { time }^{2}\end{array}$ & \multicolumn{4}{c}{ Stocking rate treatment ${ }^{3}$ (tons $\cdot$ ha $^{-1}$ ) } \\
\cline { 2 - 5 } & Control & Low & Medium & High \\
\hline Start & $4.01 \mathrm{a}$ & $4.69 \mathrm{a}$ & $4.17 \mathrm{a}$ & $4.68 \mathrm{a}$ \\
Middle & $4.58 \mathrm{a}$ & $4.58 \mathrm{a}$ & $4.32 \mathrm{a}$ & $3.85 \mathrm{~b}$ \\
End & $3.10 \mathrm{a}$ & $3.52 \mathrm{~b}$ & $3.24 \mathrm{~b}$ & $2.28 \mathrm{c}$ \\
\hline
\end{tabular}

${ }^{1}$ Stocking rate treatments; Control $=$ no cows, Low $=2.16 \mathrm{ha} \cdot \mathrm{cow}^{-1}$, Medium $=1.62$ $\mathrm{ha} \cdot \mathrm{cow}^{-1}$, and $\mathrm{High}=1.41 \mathrm{ha} \cdot \operatorname{cow}^{-1}$. Years 1,2 , and 4 are included in the analysis. Winter forage data not collected in Year 3 because of wild fire.

${ }^{2}$ Collection times correspond to Start $=$ October, Middle $=$ February, and End $=$ April.

${ }^{3}$ Means with different lowercase letters within stocking rate treatment and across collection times differ; $P<0.05$. Pooled SEM $=0.22$.

$(P>0.05)$ among stocking rate treatments at the start (April) of summer grazing; however, available forage was less $(P<0.05)$ for the high stocking rate at the end of summer grazing compared to all other treatments (Table 2). These production responses are normal for summer bahiagrass pastures in Florida (Muchovej and Mullahey 2000).

Percentage forage utilization in winter pastures did not differ $(P=0.79)$ among the 3 production years (Year 3 excluded because of wild fire). Although not statistically significant $(P=0.13)$, forage utilization was numerically greater during Years 1 and 2 compared to Year 4 (Table 3). This response is likely because of improved winter growing conditions in Year 4. Percentage forage utilization in winter pastures did not differ $(P>0.05)$ from the middle to end collections in Years 1 and 2, but was greater $(P<0.01)$ at the end compared to middle collection in Year 4 (Table 3).

Forage utilization in the summer pastures was less at the end collection, compared to the middle collection in Years 1, 3, and 4 (average percentage forage utilization of summer pastures $=32.0 \%$ and $19.5 \%$ for the middle and end collection, respectively; pooled SEM $=2.4)$. There was a significant $(P<0.01)$ interaction between year and stocking rate treatment for the utilization of summer pasture forage. Although there was variation in response across years, the high stocking rate treatment generally experienced the greatest amount of summer forage utilization (Table 4).

There were no effects of stocking rate treatment on forage CP and IVOMD in winter pastures for Years 1,2, and 3. There was a production year $\times$ collection time interaction $(P<0.01)$ for

Table 2. Effect of stocking rate treatment on average available forage at the start, middle, and end of summer grazing over 4 complete production years.

\begin{tabular}{lcccc}
\hline $\begin{array}{c}\text { Collection } \\
\text { time }^{2}\end{array}$ & \multicolumn{3}{c}{ Stocking rate treatment } & 1,3 $\left(\right.$ tons $\cdot \mathrm{ha}^{-1}$ ) \\
\cline { 2 - 5 } & Control & Low & Medium & High \\
\hline Start & $2.70 \mathrm{a}$ & $2.29 \mathrm{a}$ & $2.24 \mathrm{a}$ & $2.01 \mathrm{a}$ \\
Middle & $4.08 \mathrm{a}$ & $3.02 \mathrm{~b}$ & $2.57 \mathrm{ab}$ & $2.03 \mathrm{~b}$ \\
End & $3.81 \mathrm{a}$ & $3.47 \mathrm{a}$ & $3.42 \mathrm{a}$ & $2.60 \mathrm{~b}$ \\
\hline
\end{tabular}

${ }^{1}$ Stocking rate treatments; Control $=$ no cows, Low $=1.35$ ha $\cdot \operatorname{cow}^{-1}$, Medium $=1.01$ ha $\cdot \mathrm{cow}^{-1}$, and $\mathrm{High}=0.58 \mathrm{ha} \cdot \mathrm{COW}^{-1}$.

${ }^{2}$ Collection times correspond to Start $=$ April, Middle $=$ July, and End $=$ September.

${ }^{3}$ Means with different lowercase letters within collection time and across stocking rate treatments differ, $P<0.05$; Pooled $\mathrm{SEM}=0.24$; Treatment $\times$ Collection time, $P=0.003$.
Table 3. Effect of collection time on percentage forage utilization during the winter grazing months over 3 complete production years.

\begin{tabular}{lcc}
\hline $\begin{array}{l}\text { Annual } \\
\text { cycle }^{2}\end{array}$ & \multicolumn{2}{c}{ Collection time $^{1,3}(\%)$} \\
\cline { 2 - 3 } 1 & Middle & End \\
\hline 2 & $23.0 \mathrm{a}$ & $18.7 \mathrm{a}$ \\
4 & $24.4 \mathrm{a}$ & $25.3 \mathrm{a}$ \\
\hline
\end{tabular}

${ }^{1}$ Collection times correspond to Middle $=$ February, and End $=$ April.

${ }^{2}$ Time $\times$ Cycle; $P=0.05$. Data not collected during Year 3 because of wild fire.

${ }^{3}$ Means with different lowercase letters within annual cycle and across collection times differ, $P<0.05 ;$ pooled SEM $=5.6$.

forage quality (Table 5). Crude protein concentrations were consistently greater $(P<0.05)$ at the conclusion (end) compared to the start of winter grazing (average CP concentration $=57$ and $88 \mathrm{~g} \cdot \mathrm{kg}^{-1}$ for the start and end of winter grazing, respectively). Forage IVOMD was low (range 214-444 $\mathrm{g} \cdot \mathrm{kg}^{-1}$ ) and did not appear to correspond to any collection time. Summer forages had a greater nutrient quality compared to winter forage (Table 6). Concentrations of IVOMD did not appear to correspond to different collection times; however, pastures with the increased stocking rates (medium and high) did contain forages with greater $(P=0.03)$ IVOMD compared to nongrazed and low stocking rate pastures $(372,377,415$, and $431 \mathrm{~g} \cdot \mathrm{kg}^{-1}$ for nongrazed (control), low, medium, and high stocking rates, respectively; pooled SEM $=0.95$ ). In summer, but not winter months, forage CP concentration exceeded 80 $\mathrm{g} \cdot \mathrm{kg}^{-1}$ in all collection times. This response is likely an effect of spring pasture fertilization with N. Williams et al. (2002) reported similar results in central Florida, except that on moderately fertilized pastures $\left(60 \mathrm{~kg} \mathrm{~N} \cdot \mathrm{ha}^{-1}\right)$, CP levels declined below $80 \mathrm{~g} \cdot \mathrm{kg}^{-1}$ by July in 2 of 3 years. According to Wilkinson and Langdale (1974), adequate $\mathrm{N}$ concentrations for bahiagrass range from 18 to $22 \mathrm{~g} \cdot \mathrm{kg}^{-1}$, corresponding to 113 and $138 \mathrm{~g} \cdot \mathrm{kg}^{-1} \mathrm{CP}$, respectively. Thus, $\mathrm{CP}$ values in the summer pastures were low, especially at the end of the summer grazing cycle. Crude protein content of forage consumed by cattle should be a minimum of $80 \mathrm{~g} \cdot \mathrm{kg}^{-1}$ to supply sufficient $\mathrm{N}$ for ruminal microorganisms. Although $\mathrm{CP}$ concentration of hand-clipped samples often fell below this threshold, forage quality consumed by cattle is normally higher than the quality of forage on offer because of selective grazing (Hodgson 1982).

Table 4. Effect of stocking rate treatment on average (middle and end) percentage forge utilization during summer grazing.

\begin{tabular}{|c|c|c|c|}
\hline \multirow{2}{*}{$\begin{array}{c}\text { Annual } \\
\text { cycle }\end{array}$} & \multicolumn{3}{|c|}{ Stocking rate treatment ${ }^{1,2}(\%)$} \\
\hline & Low & Medium & High \\
\hline 1 & $30.5 a$ & $30.5 a$ & $30.7 \mathrm{a}$ \\
\hline 2 & $14.9 b$ & $5.1 \mathrm{a}$ & $26.3 \mathrm{c}$ \\
\hline 3 & $14.2 \mathrm{a}$ & $22.2 \mathrm{a}$ & $30.9 b$ \\
\hline 4 & $24.7 a b$ & $15.7 \mathrm{a}$ & $32.1 \mathrm{~b}$ \\
\hline
\end{tabular}


Table 5. Effect of collection time on measures of winter forage quality over 3 complete production years.

\begin{tabular}{|c|c|c|c|c|}
\hline \multirow{2}{*}{$\begin{array}{c}\text { Production } \\
\text { year }^{2}\end{array}$} & \multirow[b]{2}{*}{ Item } & \multicolumn{3}{|c|}{ Collection time $\mathrm{e}^{1,3}\left[\mathrm{~g} \cdot \mathrm{kg}^{-1}\right.$ (DM basis)] } \\
\hline & & Start & Middle & End \\
\hline \multirow[t]{2}{*}{1} & $\mathrm{CP}$ & $50 \mathrm{c}$ & $124 a$ & $99 b$ \\
\hline & IVOMD & $242 c$ & $444 a$ & $349 b$ \\
\hline \multirow[t]{2}{*}{2} & $\mathrm{CP}$ & $58 b$ & $46 b$ & $81 a$ \\
\hline & IVOMD & $287 a$ & $214 b$ & $317 a$ \\
\hline \multirow[t]{2}{*}{3} & $\mathrm{CP}$ & $62 b$ & $61 b$ & $83 a$ \\
\hline & IVOMD & $297 a$ & $248 b$ & $225 b$ \\
\hline
\end{tabular}

${ }^{1}$ Collection times correspond to Start $=$ October, Middle $=$ February, and End $=$ April.

${ }^{2}$ Forage quality not determined during Year 4.

${ }^{3}$ Means with different lowercase letters within collection times and across production years differ; $P<0.05$. Pooled SEM $=5.3$ and 13.1 for CP and IVOMD, respectively.

\section{Animal Performance}

Cows entering winter pastures had similar body condition across all stocking rate treatments (Table 7). However, cows assigned to the high stocking rate had a numerical, but nonsignificant $(P=0.17)$ decline in body condition compared with cows assigned to the low and medium stocking rates during the winter grazing period. This difference in body condition declined following the summer grazing period, as cattle assigned to medium and high stocking rates regained this lost body condition. Therefore, at weaning, cows from all stocking densities had similar body condition.

Calf performance during the summer grazing period was similar, irrespective of stocking rate (Table 8). Production, as measured by $\mathrm{kg}$ of calf weaned per ha of dedicated land, was greatest $(P<0.001)$ for high compared to medium and low stocking rates.

Stocking density had no impact $(P=0.94)$ on cow pregnancy rate $(89 \%, 89 \%$, and $87 \%$ for low, medium, and high stocking densities, respectively). Many of Florida's beef cows are bred in the winter to calve in the following fall. This is done in an attempt to wean calves in the midsummer (July-August) when prices tend to be more favorable compared to late fall. The downside to this program is that cows are lactating and being bred at a time of the year when pasture forage is often limiting. Higher stocking rates result in less available forage. This decrease in available forage must be compensated by an

Table 6. Effect of collection time on measures of summer forage quality over 3 complete production years.

\begin{tabular}{llccc}
\hline $\begin{array}{c}\text { Production } \\
\text { year }^{2}\end{array}$ & Item & \multicolumn{3}{c}{ Collection time $^{1,3}[\%$ (DM basis) $]$} \\
\cline { 2 - 5 } 1 & Start & Middle & End \\
\hline \multirow{3}{*}{2} & CP & $95 \mathrm{~b}$ & $111 \mathrm{a}$ & $96 \mathrm{~b}$ \\
& IVOMD & $400 \mathrm{~b}$ & $489 \mathrm{a}$ & $408 \mathrm{~b}$ \\
3 & CP & $129 \mathrm{a}$ & $110 \mathrm{~b}$ & $85 \mathrm{c}$ \\
& IVOMD & $389 \mathrm{a}$ & $395 \mathrm{a}$ & $313 \mathrm{~b}$ \\
& CP & $139 \mathrm{a}$ & $90 \mathrm{~b}$ & - \\
\hline
\end{tabular}

${ }^{1}$ Collection times correspond to Start $=$ October, Middle $=$ February, and End $=$ April.

${ }^{2}$ Forage quality not determined during Year 4 and the end collection of Year 3.

${ }^{3}$ Means with different lowercase letters within collection times and across production years differ; $P<0.05$. Pooled SEM $=5.9$ and 9.4 for CP and IVOMD, respectively.
Table 7. Effect of cow stocking rate on average cow body condition score over 3 production cycles.

\begin{tabular}{lccrrr}
\hline & \multicolumn{3}{c}{ Stocking rate $^{1}(\mathrm{BCS})^{3}$} & & \\
\cline { 2 - 4 } \multicolumn{1}{c}{ Item $^{2}$} & Low & Medium & High & SEM & $P$ \\
\hline Enter winter pastures & 5.6 & 5.6 & 5.4 & 0.14 & 0.54 \\
Enter summer pastures & 5.6 & 5.1 & 4.8 & 0.28 & 0.30 \\
Weaning & 5.8 & 5.9 & 5.4 & 0.15 & 0.21 \\
BCS change in winter & 0.0 & -0.5 & -0.6 & 0.16 & 0.17 \\
BCS change in summer & 0.3 & 0.8 & 0.7 & 0.22 & 0.34 \\
\hline
\end{tabular}

${ }^{1}$ Stocking rate treatments $=2.16,1.62$, and 1.41 , and $1.35,1.01$, and $0.58 \mathrm{ha} \cdot \mathrm{cow}^{-1}$ for low, medium, and high stocking rates in winter and summer pastures, respectively.

${ }^{2}$ Cows entered winter pastures in October, entered summer pastures in April, and were weaned in September.

${ }^{3} \mathrm{BCS}=$ cow body condition score based on a 1-9 scale $(1=$ emaciated and $9=$ obese $)$.

increase in supplementation; otherwise cows will suffer a loss in body condition score. Hodgson (1982) observed that restricted nutrient intake is likely the greatest factor contributing to lower production of grazing animals with about twice the variability as that for diet quality. He noted that diet quality varies by a factor of about 2, whereas the herbage intake may vary by a factor of at least 4 .

Decreased cow body condition is a primary contributor to reduced conception rates in beef cattle. A Florida study evaluating over 3700 beef cows reported a 30\% decline in pregnancy rate for cows with body condition scores less than 4.0 compared to cows with a body condition score greater than 5.0 (Rae et al. 1993). In the current study, the high and medium stocking rates resulted in a decrease in cow body condition while grazing winter pastures, although body condition remained at 4.0 or above. These pastures are considered unimproved and were unable to support adequate forage yield for the maintenance of cow body condition at the medium and high stocking rate. Selk et al. (1988) reported a significant correlation between cow body condition scores less than 4.0 and increases in post-partum interval as well as decreased cow pregnancy rate. Despite numeric differences in cow body condition in the current study, stocking rate did not affect cow pregnancy rate, suggesting that the body condition scores realized in this study were not low enough to significantly affect cow production. Calf birth date was not recorded in this study;

Table 8. Effect of cow stocking rate on average calf performance over 4 production cycles.

\begin{tabular}{|c|c|c|c|c|c|}
\hline \multirow[b]{2}{*}{ Item } & \multicolumn{3}{|c|}{ Stocking rate ${ }^{1}(\mathrm{~kg})$} & \multirow[b]{2}{*}{ SEM } & \multirow[b]{2}{*}{$P$} \\
\hline & Low & Medium & High & & \\
\hline Enter summer pastures & 176.9 & 169.6 & 156.9 & 10.9 & 0.51 \\
\hline Weaning & 255.3 & 245.4 & 235.4 & 8.2 & 0.36 \\
\hline$A D G$ & 0.89 & 0.86 & 0.88 & 0.04 & 0.86 \\
\hline Production, $\mathrm{kg} \cdot \mathrm{ha}^{-1,2}$ & $70.3 a$ & $90.2 b$ & $146.8 \mathrm{c}$ & 2.94 & $<0.01$ \\
\hline
\end{tabular}

${ }^{1}$ Stocking rate treatments $=1.35,1.01$, and $0.58 \mathrm{ha} \cdot \mathrm{cow}^{-1}$ for low, medium, and high stocking rates in summer pastures, respectively. Cows entered summer pastures in April and were weaned in September. All measures of calf data are adjusted for sex.

${ }^{2}$ Production $/$ ha $=$ [average weaning rate for all treatments] $\times$ [sex-adjusted calf weaning weight] $\times$ [stocking rate $(15,20$, or 35$)] / 52.7$ ha. Means with different lowercase letters within item differ $(P<0.01)$. 
Table 9. Annual cow-calf operating expenses from Buck Island Ranch grouped by costs dependent on herd size and costs independent of herd size. ${ }^{1,2}$

\begin{tabular}{lc}
\hline \multicolumn{1}{c}{ Costs dependent on herd size } & Annual costs (1999-2003 avg) \\
\hline Purchased feed & $\$ 156459$ \\
Pasture fertilization & $\$ 43196$ \\
Veterinary \& medical supplies & $\$ 81259$ \\
Hired labor (day riders) & $\$ 105827$ \\
Brood cow/ bull depreciation & $\$ 142449$ \\
Repairs and maintenance & $\$ 48914$ \\
Miscellaneous (incl. cattle shipping freight) & $\$ 12265$ \\
Costs dependent of herd size & $\$ 590368$ \\
Cost per head (3 000 hd) & $\$ 197$ hd $^{-1}$
\end{tabular}

\begin{tabular}{lc}
\multicolumn{1}{c}{ Costs independent of herd size } & Annual costs (1999-2003 avg) \\
\hline Building/vehicle depreciation & $\$ 63419$ \\
Ranch management labor ${ }^{3}$ & $\$ 70551$ \\
Insurance & $\$ 16245$ \\
Utilities & $\$ 6390$ \\
Professional services, custom hire, rentals & $\$ 16238$ \\
Supplies, travel, postage & $\$ 11434$ \\
Horse feed and pasture weed spray & $\$ 8843$ \\
Gas/fuel/oil & $\$ 23139$ \\
Property taxes & (1) \\
Costs independent of herd size & $\$ 45000$ \\
Cost per head (3 000 hd) & $\$ 261259$ \\
Total annual operating costs with 3000 & $\$ 87$ hd $^{-1}$ \\
\end{tabular}
brood cows

Total annual cost per head

$\$ 284 \mathrm{hd}^{-1}$

${ }^{1}$ Costs based on annual expenditures as reported through SPA (Standardized Performance Analysis) records for 1999-2003.

${ }^{2}$ Costs adjusted by the CPI index: $1999=1.00,2000=1.03,2001=1.06,2002=1.08$, and $2003=1.10$ (Bureau of Labor Statistics 2006).

${ }^{3}$ Labor costs include health, retirement, and other nonwage benefits. Day riders and part-time labor assumed to be $60 \%$ of total labor costs. Ranch management salaries assumed to be $40 \%$ of total labor costs.

${ }^{4}$ As a nonprofit entity, Buck Island Ranch is exempt from local property taxes. $\$ 11$ ha $^{-1}$ of summer improved pastures are added to annual costs to represent typical ranching costs in the region.

therefore time of conception was not determined. It is possible that the lower body condition of the high and medium stocking rate cows resulted in a delay in conception providing younger calves the following year.

Each of the stocking densities allowed adequate available forage in the summer pastures. Cows on the medium and high stocking densities regained their lost body condition by the time of weaning and were not different from the cows on the low stocking rate at that time. Coleman et al. (2001) also found that losses in cow body condition during winter and spring lactation were recovered by the end of summer grazing. The high stocking density used in this study is more similar to common Florida beef cow/calf production practices. In this evaluation, the high stocking density supported similar cow and calf performance for a complete production cycle as the lower stocking densities. When pasture productivity was considered, the high stocking density provided the most weight of weaned calf per unit of dedicated land (Table 8).
Table 10. Herd size, operating costs, break-even calf prices, and profit potential between 1999 and 2003 corresponding to stocking rate treatments.

\begin{tabular}{|c|c|c|c|}
\hline & \multicolumn{3}{|c|}{ Stocking rate treatments } \\
\hline & $\begin{array}{l}\text { High }(0.58 \\
\left.\text { ha } \cdot \operatorname{cow}^{-1}\right)\end{array}$ & $\begin{array}{l}\text { Medium }(1.01 \\
\left.\text { ha } \cdot \operatorname{cow}^{-1}\right)\end{array}$ & $\begin{array}{l}\text { Low }(1.35 \\
\left.\text { ha } \cdot \operatorname{cow}^{-1}\right)\end{array}$ \\
\hline 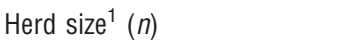 & 3000 & 1723 & 1289 \\
\hline Weaned calves ${ }^{2}(71 \%)$ & 2130 & 1223 & 915 \\
\hline $\begin{array}{l}\text { Costs dependent on herd } \\
\text { size (Table 9) }\left(\$ 197 \cdot \mathrm{hd}^{-1}\right)\end{array}$ & $\$ 590368$ & $\$ 339431$ & $\$ 253933$ \\
\hline $\begin{array}{l}\text { Costs independent on } \\
\text { herd size (Table 9) }\left(\$ \cdot y^{-1}\right)\end{array}$ & $\$ 261259$ & $\$ 261259$ & $\$ 261259$ \\
\hline Total costs $\left(\$ \cdot y^{-1}\right)$ & $\$ 851627$ & $\$ 600690$ & $\$ 515192$ \\
\hline Costs per calf ${ }^{3}\left(\$ \cdot\right.$ calf $\left.^{-1}\right)$ & $\$ 400$ & $\$ 491$ & $\$ 563$ \\
\hline Break-even price $\left(\$ \cdot \mathrm{kg}^{-1}\right)$ & $\$ 1.89$ & $\$ 2.32$ & $\$ 2.66$ \\
\hline Profit potential ${ }^{4}$ (1999-2003) & 3 of $5 y$ & 0 of $5 y$ & 0 of $5 y$ \\
\hline
\end{tabular}

${ }^{1}$ Stocking rates based on 1740 ha of summer improved pastures.

${ }^{2}$ Weaning rate of $71 \%$ is 5-y average (1999-2003) based on SPA records.

${ }^{3}$ Wean calf weight of $212 \mathrm{~kg}$ is $5-y$ average (1999-2003) based on SPA records.

${ }^{4}$ Reported prices received by Buck Island Ranch (weighted average across all sales of steers and heifers): 1999: $\$ 1.65 \mathrm{~kg}^{-1}\left(\$ 75.20 \mathrm{cwt}^{-1}\right) ; 2000: \$ 2.08 \mathrm{~kg}^{-1}\left(\$ 94.44 \mathrm{cwt}^{-1}\right)$; 2001: $\$ 2.23 \mathrm{~kg}^{-1}\left(\$ 101.34 \mathrm{cwt}^{-1}\right) ; 2002: \$ 1.81 \mathrm{~kg}^{-1}\left(\$ 82.12 \mathrm{cwt}^{-1}\right) ; 2003: \$ 2.11 \mathrm{~kg}^{-1}$ $\left(\$ 96.04 \mathrm{cwt}^{-1}\right)$.

\section{Economic Viability}

Table 9 lists the cost categories for which SPA data were collected and summarizes the average annual cost data for the commercial cow-calf operation on Buck Island Ranch. Annual cost data are adjusted using the CPI index so that costs were expressed relative to 1999 as the base year.

Between 1999 and 2003, total inflation-adjusted costs to support 3000 brood cows averaged nearly $\$ 852000$ per year. Materials, supplies, and labor that were dependent on herd size accounted for $69 \%$ of total costs, or $\$ 197$ per cow. The remaining costs, $\$ 261627$ or $31 \%$ of total costs, were attributed to cost categories that were independent of herd size and therefore were assumed not to change with reductions in cattle stocking rates.

Table 10 outlines how herd size, total costs, total unit calf costs, and break-even prices would have changed if the lower stocking rate treatments had been imposed on the existing commercial operation. Total pasture area remained constant. Specific stocking rates were achieved by reducing the number of brood cows over the entire ranch.

As stocking rates on the summer pastures decreased from 0.58 to $1.01 \mathrm{ha} \cdot \mathrm{cow}^{-1}$, herd size declined from 3000 to 1723 brood cows. When stocking rate decreased further to 1.35 ha $\cdot \mathrm{cow}^{-1}$, herd size declined to 1289 brood cows. Between 1999 and 2003, the Ranch averaged annual calf crop percentages and weaning weights of $71 \%$ and $212 \mathrm{~kg}$, respectively. Given that the current study found no significant difference on livestock performance parameters under the selected stocking treatments, weaned calf crop percentage and average weaning weight remained constant across stocking rates.

Costs that were dependent on herd size declined from $\$ 590368$ at the highest stocking rate to $\$ 253933$ at the lowest stocking rate (Table 10). Costs independent of herd size remain constant at $\$ 261259$ per year. Total cost of ranching 
operations decreased from $\$ 851627$ at the high stocking rate to $\$ 514933$ per year at the lowest stocking rate. The unit cost of calf production, however, increased $41 \%$, from $\$ 400$ per calf at the highest stocking rate to $\$ 563$ per calf at the lowest stocking rate. Break-even calf prices, or the price needed at the time of weaning to recover all calf costs, increased from $\$ 1.89$ $\mathrm{kg}^{-1}\left(\$ 85 \mathrm{cwt}^{-1}\right)$ at the highest stocking rate to $\$ 2.32 \mathrm{~kg}^{-1}$ $\left(\$ 105 \mathrm{cwt}^{-1}\right)$ at the medium stocking rate to $\$ 2.66 \mathrm{~kg}^{-1}(\$ 120$ $\mathrm{cwt}^{-1}$ ) at the lowest stocking rate. Comparing break-even prices with actual calf prices received by Buck Island Ranch between 1999 and 2003 indicates that at the highest stocking rate $\left(0.58 \mathrm{ha} \cdot \mathrm{cow}^{-1}\right)$, a ranch similar to Buck Island would have received positive net income during 3 of the 5 years. At either the medium or the low stocking rates, however, a rancher would have lost income in every year between 1999 and 2003.

\section{IMPLICATIONS}

The stocking rates used in this study had minimal effects on forage utilization or cattle performance but had a large effect on total production and profitability. Cow body condition during a complete production cycle was not affected by stocking rate, although cows at the high stocking rate tended to have a lower body condition at the end of the winter grazing cycle. Pregnancy rate and calf weaning weight were not affected by stocking rate. Consequently, a change in stocking rate has a one-to-one relationship with ranch revenues. If stocking rates decrease by $10 \%$, ranch revenues fall by $10 \%$ as well. At the same time, unit cow costs increase at an increasing rate as fewer brood cows are left to support the portion of the ranch's operating budget that is independent of herd size. Without any offsets in improved calving percentages, weaning weights, or other measures of livestock performance, the inevitable outcome of lower stocking rate is impaired profit potential.

The study of animal and forage production under alternative stocking rates fits within a larger research agenda to determine whether cattle stocking rates have a direct consequence on surface water quality within the Lake Okeechobee region of southern Florida. If lower stocking rates have a positive effect on surface water quality, the lost profits from fewer brood cows serves as a starting point for a discussion of how much water quality improvements are worth. A separate, but related, discussion begins concerning whether ranchers are entitled to compensation when serving the larger good (i.e., improved water quality) comes at an individual cost (i.e., lower ranch income).

\section{LITERATURE CITED}

Bureau of Labor Statistics, USDOL. 2006. Consumer Price Index Calculator. Available at: http://data.bls.gov/cgi-bin/cpicalc.pl. Accessed 27 February 2006.

Capece, J. C., K. L. Campbell, P. J. Bohlen, D. A. Graetz, and K. M. Portier. 2007. Soil phosphorus, cattle stocking rates, and water quality in subtropical pastures in Florida, USA. Rangeland Ecology \& Management 60:19-30.

Coleman, S. W., W. A. Phillips, J. D. Volesky, and D. Buchanan. 2001. A comparison of native tallgrass prairie and plains bluestem forage systems for cow-calf production in the southern great plains. Journal of Animal Science 79:16971705.

Gallaher, R. N., C. O. Weldon, and J. G. Futral. 1975. An aluminum block digester for plant and soil analysis. Proceedings of the American Soil Science Society 39:803-806.

Hambleton, L. G. 1977. Semiautomated method for simultaneous determination of phosphorus, calcium and crude protein in animal feeds. Journal of the Association of Official Analytical Chemists 60:845-852.

HodGson, J. 1982. Influence of sward characteristics on diet selection and herbage intake by the grazing animal. In: J. B. Hacker [ED]. Nutritional limits to animal production from pastures. Slough, UK: CAB. p 153-166.

McGrann, J. M. 1995. IRM-SPA Handbook—standardized performance analysis, SPA-1. College Station, TX: Texas Agricultural Extension Service.

McSorley, R., and G. W. Tanner. 2007. Effects of cattle stocking rates on nematode communities in south Florida. Rangeland Ecology \& Management 60:31-35.

Moore, J. E., AND G. O. Mott. 1974. Recovery of residual organic matter from in vitro digestion of forages. Journal of Dairy Science 57:1258-1259.

Muchoves, R. M., And J. J. Mullahey. 2000. Yield and quality of five bahiagrass cultivars in southwest Florida. Proceedings of the Florida Soil and Crop Science Society 59:82-84.

Rae, D. O., W. E. Kunkle, P. J. Chenoweth, R. S. Sand, and T. Tran. 1993. Relationship of parity and body condition score to pregnancy rates in Florida beef cattle. Theriogenology 39:1143-1152.

Selk, G. E., R. P. Wettemann, K. S. Lusby, J. W. Oltjen, S. L. Mobley, R. J. Rasby, AND J. C. GaRMENDIA. 1988. Relationships among weight change, body condition and reproductive performance of range beef cows. Journal of Animal Science 66:3153-3159.

Swain, H. M., P. J. Bohlen, K. L. Campbell, L. O. Lollis, and A. D. Steinman. 2007. Integrated ecological and economic analysis of ranch management systems: an example from South Central Florida. Rangeland Ecology \& Management 60:1-11.

USDA-NASS. 2006. Cattle inventory, January 1, 2006: cows that calved-beef. Washington, DC: National Agricultural Statistics Service, Agricultural Statistics Board, United States Department of Agriculture. Available at: http:// www.nass.usda.gov:8080/QuickStats/PullData_US.jsp. Accessed 5 October 2006.

Wilkinson, S. R., and G. W. Langdale. 1974. Fertility needs of the warm-season grasses. In: Forage fertilization. ASA, Madison, WI: ASA. p 119-145.

Williams, M. J., C. C. Chase, JR., And A. C. Hammond. 2002. Diet quality and performance of heifers in the subtropics. Agronomy Journal 94:88-95. 